\title{
Deciphering potential chemical compounds of gaseous oxidized mercury in Florida, USA
}

\author{
Jiaoyan Huang ${ }^{1}$, Matthieu B. Miller ${ }^{2}$, Eric Edgerton ${ }^{3}$, and Mae Sexauer Gustin ${ }^{2}$ \\ ${ }^{1}$ Institute for the Environment, University of North Carolina, Chapel Hill, 100 Europa Drive, Suite 490, Chapel Hill, \\ NC, 27517, USA \\ ${ }^{2}$ Department of Natural Resources and Environmental Sciences, University of Nevada-Reno, 1664 N. Virginia Street, \\ Reno, NV, 89557, USA \\ ${ }^{3}$ Atmospheric Research \& Analysis, Inc., 410 Midenhall Way, Cary, North Carolina 27513, USA \\ Correspondence to: Mae Sexauer Gustin (mgustin@cabnr.unr.edu)
}

Received: 10 August 2016 - Published in Atmos. Chem. Phys. Discuss.: 2 November 2016

Revised: 29 December 2016 - Accepted: 5 January 2017 - Published: 3 February 2017

\begin{abstract}
The highest mercury $(\mathrm{Hg})$ wet deposition in the United States of America (USA) occurs along the Gulf of Mexico, and in the southern and central Mississippi River Valley. Gaseous oxidized Hg (GOM) is thought to be a major contributor due to high water solubility and reactivity. Therefore, it is critical to understand concentrations, potential for wet and dry deposition, and GOM compounds present in the air. Concentrations and dry-deposition fluxes of GOM were measured and calculated for Naval Air Station Pensacola Outlying Landing Field (OLF) in Florida using data collected by a Tekran ${ }^{\circledR} 2537 / 1130 / 1135$, the University of Nevada Reno Reactive Mercury Active System (UNRRMAS) with cation exchange and nylon membranes, and the Aerohead samplers that use cation-exchange membranes to determine dry deposition. Relationships with Tekran ${ }^{\circledR}$ derived data must be interpreted with caution, since the GOM concentrations measured are biased low depending on the chemical compounds in air and interferences with water vapor and ozone.

Criteria air pollutants were concurrently measured. This allowed for comparison and better understanding of GOM.

In addition to other methods previously applied at OLF, use of the UNRRMAS provided a platform for determination of the chemical compounds of GOM in the air. Results from nylon membranes with thermal desorption analyses indicated seven GOM compounds in this area, including $\mathrm{HgBr}_{2}, \mathrm{HgCl}_{2}, \mathrm{HgO}, \mathrm{Hg}$-nitrogen and sulfur compounds, and two unknown compounds. This indicates that the site is influenced by different gaseous phase reactions and sources.
\end{abstract}

Using back-trajectory analysis during a high-GOM event related to high $\mathrm{CO}$, but average $\mathrm{SO}_{2}$, indicated air parcels moved from the free troposphere and across Arkansas, Mississippi, and Alabama at low elevation $(<300 \mathrm{~m})$. This event was initially characterized by $\mathrm{HgBr}_{2}$, followed by a mixture of GOM compounds. Overall, GOM chemistry indicates oxidation reactions with local mobile source pollutants and long-range transport.

In order to develop methods to measure GOM concentrations and chemistry, and model dry-deposition processes, the actual GOM compounds need to be known, as well as their corresponding physicochemical properties, such as Henry's Law constants.

\section{Introduction}

Mercury $(\mathrm{Hg})$ has been classified as a persistent, bioaccumulative toxin (PBT) (UNEP, 2013), and deposition from the atmosphere is considered the dominant pathway by which $\mathrm{Hg}$ enters remote ecosystems (Lindberg et al., 2007). In some areas, scavenging by precipitation controls atmospheric $\mathrm{Hg}$ removal processes, such as in the southeastern United States of America (USA), where precipitation amounts are high (Prestbo and Gay, 2009). However, wet deposition concentrations are not necessarily correlated with precipitation amounts $>81 \mathrm{~mm}$, and deposition has not decreased with emission reductions as coal combustion facilities in the region have implemented control technologies (Prestbo and 
Gay, 2009; MDN, 2014). For example, fluxes at Naval Air Station Pensacola Outlying Landing Field (OLF) in Florida were $17.1 \mu \mathrm{g} \mathrm{m}^{-2}$ in 2012 and $21.0 \mu \mathrm{g} \mathrm{m}^{-2}$ in 2014 (MDN, 2014). A contributing factor to wet deposition in the Gulf Coast area may be related to high atmospheric convection during thunderstorms and scavenging of gaseous oxidized $\mathrm{Hg}$ (GOM) from the free troposphere (Nair et al., 2013), as well as down-mixing of air with high GOM from the free troposphere (Gustin et al., 2012).

An additional concern is that the Tekran ${ }^{\circledR}$ system measurement currently used to quantify GOM does not equally quantify all GOM forms, and has interferences with water vapor and ozone (cf. Ambrose et al., 2013; Gustin et al., 2013; Huang et al., 2013; Lyman et al., 2010, 2016; McClure et al., 2014). Since GOM is considered an important form that can be rapidly removed from the atmosphere due to high water solubility (Lindberg et al., 2007), it is important to understand both atmospheric concentrations and chemistry (i.e., specific chemical compounds). Use of the University of Nevada Reno Reactive Mercury Active System (UNRRMAS) that collects GOM on nylon membranes in tandem with cation exchange membranes has indicated that there are different chemical compounds in the air and concentrations are 2 to 13 times higher than previously thought at locations in the western USA (Huang et al., 2013; Gustin et al., 2016).

Mercury has been studied in Florida for many years, initially because of the high concentrations measured in fish and Florida panthers (Dvonch et al., 1999; Gustin et al., 2012; Marsik et al., 2007; Pancras et al., 2011; Peterson et al., 2012). Long-term GEM and GOM concentrations as measured by the Tekran ${ }^{\circledR}$ system have declined; however, PBM concentrations increased after 2009 (Edgerton, unpublished data), suggesting the atmospheric chemistry has changed. Peterson et al. (2012) and Gustin et al. (2012) suggested, based on detailed assessment of passive sampler and Tekran ${ }^{\circledR}$ system collected $\mathrm{Hg}$ data, criteria air pollutants, and meteorology, that at three locations in Florida (OLF, Davie, and Tampa) different GOM compounds were present, and these were generated by in situ oxidation associated with pollutants generated by mobile sources, indirect and direct inputs of $\mathrm{Hg}$ from local electricity generating plants, and direct input of $\mathrm{Hg}$ associated with long-range transport. At OLF, background deposition was equal to that associated with mobile sources, and a significant component was derived from longrange transport in the spring. Long-range transport has been reported for OLF in the spring (Weiss-Penzias et al., 2011; Gustin et al., 2012). Long-range transport of ozone is a very common event in the spring in the western United States (see special issues on ozone: Gertler and Bennett, 2015; Lefohn and Cooper, 2015).

In this work, GOM collected using the UNRRMAS and the Aerohead dry-deposition measurement method (Lyman et al., 2007, 2009) were analyzed along with Tekran ${ }^{\circledR} \mathrm{Hg}$ and criteria air pollutant data to understand GOM chemistry and dry deposition at OLF, located $\sim 15 \mathrm{~km} \mathrm{NW}$ of Pensacola, Florida.

GOM dry-deposition fluxes were calculated using deposition velocities determined using a multi-resistance model with ambient air GOM concentrations from the Tekran ${ }^{\circledR}$ system (multiplied by a factor of 3 due to bias in the Tekran ${ }^{\circledR}$ system; cf. Huang and Gustin, 2015), and compared to those obtained using Aerohead data. The chemistry of GOM compounds was identified. Results were used to estimate drydeposition velocities for the GOM compounds observed. The hypothesis for this work was that since GOM compounds can vary spatially and temporally, due to different compounds produced by different sources and processes, this will result in different dry-deposition velocities and dry-deposition fluxes.

\section{Methods}

\subsection{Field site}

The sampling site was located at OLF $\left(30.550^{\circ} \mathrm{N}\right.$, $87.374^{\circ} \mathrm{W}, 44 \mathrm{~m}$ a.s.1. - above sea level). The closest major $\mathrm{Hg}$ emission source is a coal-fired power plant (Plant Crist) northeast of the site (Fig. 1). This area has been used for atmospheric $\mathrm{Hg}$ research in previous studies (Caffrey et al., 2010; Lyman et al., 2009; Gustin et al., 2012; Peterson et al., 2012; Weiss-Penzias et al., 2011). OLF is a coastal site ( $\sim 25 \mathrm{~km}$ away from Gulf of Mexico) influenced by sea breezes especially during the summer (Gustin et al., 2012). Based on cluster analyses of data from 1 year at this location, $\sim 24 \%$ of the air is derived from the marine boundary layer during the day and $60 \%$ at night (Fig. 1).

\subsection{Sampling methods}

Aerohead samplers for determination of dry deposition were deployed bi-weekly from June 2012 to March 2014. UNRRAMS samples were taken bi-weekly from March 2013 to March 2014. Atmospheric Hg concentrations, including GEM, GOM, and PBM, were measured using a Tekran ${ }^{\circledR}$ system (model 2357/1130/1135, Tekran ${ }^{\circledR}$ Instrument Corp., Ontario, Canada) that was operated with $1 \mathrm{~h}$ sampling and $1 \mathrm{~h}$ desorption with detection limits of $0.1 \mathrm{ng} \mathrm{m}^{-3}, 1.5 \mathrm{pg} \mathrm{m}^{-3}$, and $1.5 \mathrm{pg} \mathrm{m}^{-3}$, respectively.

Reactive Hg (GOM + PBM) concentrations were measured using the UNRRAMS with three sets of two inseries $47 \mathrm{~mm}$ cation-exchange membranes (ICE450, Pall Corp., MI, USA). Three sets of nylon membranes $(0.2 \mu \mathrm{m}$, Cole-Parmer, IL, USA) were also deployed to assess $\mathrm{Hg}$ compounds in the air (see Pierce and Gustin, 2017, for schematic). Cation exchange membranes have been demonstrated to quantitatively measure specific compounds of GOM in the laboratory; however, they may not measure all compounds (Gustin et al., 2015, 2016). These membranes have also been shown to retain compounds loaded for 


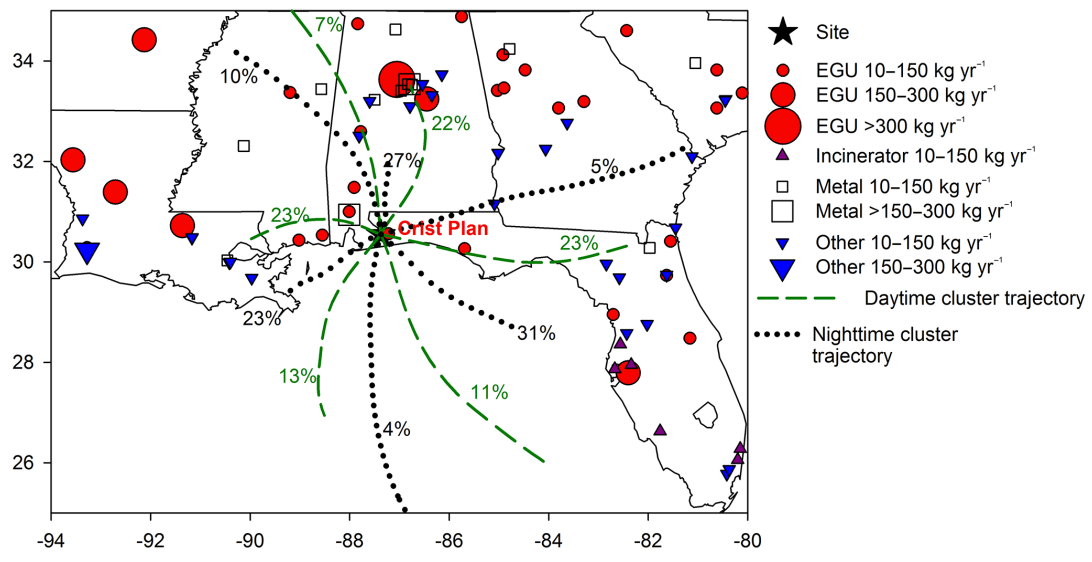

Figure 1. Sampling site and point sources (NEI 2011) map. Cluster trajectories for daytime (11:00-13:00) and nighttime (01:00-03:00). The $x$ and $y$ axes represent longitude and latitude.

3 weeks (Pierce and Gustin, 2017). Nylon membranes do not retain GOM compounds quantitatively, and retention during transport needs to be tested (Huang et al., 2013; Gustin et al., 2015, 2016). Nylon membrane retention is impacted by relative humidity that might limit uptake of specific forms. Criteria air pollutants and meteorological data, including $\mathrm{CO}$, $\mathrm{SO}_{2}, \mathrm{O}_{3}, \mathrm{PM}_{2.5}, \mathrm{NO}, \mathrm{NO}_{2}, \mathrm{NO}_{y}$, temperature, relative humidity, wind speed, wind direction, pressure, solar radiation, and precipitation were available at this site for the sampling period. See Peterson et al. (2012) for detailed information on collection of these measurements.

Aeroheads and membranes were prepared at UNR, packed in a thermal isolated cooler, and shipped back and forth between the laboratory and site. Samples were stored in a freezer $\left(-22^{\circ} \mathrm{C}\right)$ at UNR until analyzed. Cation-exchange membranes were digested and analyzed following EPA Method 1631 E (Peterson et al., 2012), and nylon membranes were first thermally desorbed, and then analyzed using EPA Method 1631 E (Huang et al., 2013). Cation-exchange membrane blanks for Aerohead and UNRRAMS were $0.40 \pm 0.18$ $(n=42), 0.37 \pm 0.26(n=77) n g$, respectively, and for nylon membranes used in the active system blanks were $0.03 \pm 0.03(n=69)$ ng. Therefore, method detection limits (MDLs, $3 \sigma$ ) for a 2-week sampling time $(336 \mathrm{~h})$ was $0.13 \mathrm{ng} \mathrm{m}^{-2} \mathrm{~h}^{-1}$ for dry deposition. For the active membrane system, the $\mathrm{Hg}$ amount on the back-up filters and blanks were not significantly different (cation-exchange membrane: $0.4 \pm 0.3$ vs. $0.4 \pm 0.3 \mathrm{ng}$; nylon membrane: $0.03 \pm 0.03$ vs. $0.02 \pm 0.02 \mathrm{ng}$ ); therefore, the back-up filters were included in the calculation of the bi-weekly blanks. The bi-weekly MDLs ( $336 \mathrm{~h}$ ) for active systems with cation-exchange and nylon membranes were $2-68 \mathrm{pg} \mathrm{m}^{-3}$ (mean: $24 \mathrm{pg} \mathrm{m}^{-3}$ ) and $0.01-14.6 \mathrm{pg} \mathrm{m}^{-3}$ (mean: $2.1 \mathrm{pg} \mathrm{m}^{-3}$ ), respectively. Biweekly MDL was calculated from 3 times the standard deviation of bi-weekly blanks. The MDL was calculated for each period of sampling, due to the fact this can vary based on treatment of the membranes, the time samples are prepared for deployment, deployment at the field site, and handling once returned to the laboratory. The membranes may also vary by material lot. All samples were corrected by subtracting the blank for the corresponding 2-week period.

\subsection{Data analyses}

Hourly Tekran ${ }^{\circledR}$, criteria air pollutants, and meteorological data were managed and validated by Atmospheric Research \& Analysis, Inc (see Peterson et al., 2012). These were then averaged into 2-week intervals to merge with the membrane measurements.

In previous studies, scaling factors similar to $\mathrm{HNO}_{3}(\alpha=$ $\beta=10$ ) were used to calculate oxidized $\mathrm{Hg}$ dry-deposition velocity (Marsik et al., 2007; Castro et al., 2012); however, Lyman et al. (2007) used the effective Henry's Law constant, and half-redox reactions in neutral solutions of $\mathrm{HgCl}_{2}$, and indicated HONO might better represent the chemical properties of oxidized $\mathrm{Hg}$ rather than $\mathrm{HNO}_{3}$. Huang and Gustin (2015a) indicated that due to limited understanding of oxidized $\mathrm{Hg}$ chemical properties, no single value can be used to calculate oxidized $\mathrm{Hg}$ dry deposition, because $\alpha$ and $\beta$ would change with different GOM compounds. Here, dry deposition was calculated using the multiple resistance model of Lyman et al. (2007) using both $\alpha=\beta=2,5,7$, and 10 .

Back trajectories were calculated using the Hybrid Single Particle Lagrangian Integrated Trajectory (HYSPLIT 4.9) model with Eta Data Assimilation System (EDAS) $40 \mathrm{~km}$, $1000 \mathrm{~m}$ starting height. For day and nighttime analyses, starting times were local standard time (LST) 11:00-13:00 and 100-300 h, $72 \mathrm{~h}$ simulations. For a high-concentration event analyses, trajectories were started for each day at 00:00, 04:00, 08:00, 12:00, 16:00, and 20:00 LST. Overall, the uncertainties of back trajectories calculated from HYSPLIT are $20 \%$ of the air-parcel traveling distance (Draxler, 2013; Gebhart et al., 2005; Stohl, 1998; Stohl et al., 2003). Back tra- 
Table 1. Overall seasonal average of criteria air pollutants, GEM, PBM, GOM (measured using three different methods) concentration, GOM dry deposition (DD), and meteorological data at OLF.

\begin{tabular}{|c|c|c|c|c|c|c|c|c|}
\hline & \multicolumn{3}{|c|}{2012} & \multicolumn{4}{|c|}{2013} & \multirow{2}{*}{$\begin{array}{r}2014 \\
\text { March }\end{array}$} \\
\hline & Summer & Fall & Winter & Spring & Summer & Fall & Winter & \\
\hline Ozone [ppb] & $30 \pm 15$ & $30 \pm 12$ & $29 \pm 11$ & $38 \pm 12$ & $24 \pm 12$ & $26 \pm 11$ & $27 \pm 10$ & $35 \pm 12$ \\
\hline $\mathrm{CO}[\mathrm{ppb}]$ & $143 \pm 38$ & $161 \pm 35$ & $167 \pm 41$ & $165 \pm 36$ & $139 \pm 35$ & $156 \pm 33$ & $167 \pm 35$ & $183 \pm 33$ \\
\hline $\mathrm{SO}_{2}[\mathrm{ppb}]$ & $0.3 \pm 0.4$ & $0.6 \pm 1.5$ & $0.4 \pm 0.5$ & $0.3 \pm 0.5$ & $0.2 \pm 0.3$ & $0.4 \pm 0.5$ & $0.7 \pm 1.2$ & $0.3 \pm 0.4$ \\
\hline NO [ppb] & $0.3 \pm 0.7$ & $0.3 \pm 0.7$ & $0.3 \pm 0.8$ & $0.2 \pm 0.5$ & $0.3 \pm 0.7$ & $0.3 \pm 0.8$ & $0.4 \pm 0.8$ & $0.2 \pm 0.5$ \\
\hline $\mathrm{NO}_{2}[\mathrm{ppb}]$ & $2.4 \pm 2.4$ & $3.0 \pm 2.7$ & $3.0 \pm 3.1$ & $2.0 \pm 2.3$ & $2.2 \pm 2.1$ & $3.1 \pm 2.9$ & $3.2 \pm 3.0$ & $2.3 \pm 2.8$ \\
\hline $\mathrm{NO}_{y}[\mathrm{ppb}]$ & $3.6 \pm 2.9$ & $4.3 \pm 3.1$ & $4.3 \pm 3.6$ & $3.1 \pm 2.8$ & $3.2 \pm 2.5$ & $4.4 \pm 3.3$ & $4.2 \pm 3.4$ & $3.6 \pm 3.1$ \\
\hline $\operatorname{GEM}\left[\mathrm{ng} \mathrm{m}^{-3}\right]^{\mathrm{a}}$ & $1.2 \pm 0.1$ & $1.2 \pm 0.1$ & $1.3 \pm 0.1$ & $1.2 \pm 0.2$ & $1.1 \pm 0.1$ & $1.0 \pm 0.1$ & $1.2 \pm 0.3$ & $1.2 \pm 0.1$ \\
\hline $\mathrm{GOM}\left[\mathrm{pg} \mathrm{m}^{-3}\right]^{\mathrm{a}}$ & $0.6 \pm 1.3$ & $1.1 \pm 2.8$ & $1.0 \pm 2.2$ & $2.9 \pm 5.1$ & $0.5 \pm 1.0$ & $1.1 \pm 2.1$ & $1.3 \pm 2.5$ & $2.0 \pm 3.6$ \\
\hline $\operatorname{PBM}\left[\mathrm{pg} \mathrm{m}^{-3}\right]^{\mathrm{a}}$ & $2.4 \pm 2.6$ & $3.6 \pm 3.8$ & $7.3 \pm 8.7$ & $5.9 \pm 6.8$ & $2.3 \pm 2.0$ & $2.9 \pm 2.3$ & $4.9 \pm 5.3$ & $4.0 \pm 3.4$ \\
\hline $\operatorname{GOM}\left[\mathrm{pg} \mathrm{m}^{-3}\right]^{\mathrm{b}}$ & - & - & - & $43 \pm 110$ & $24 \pm 57$ & $14 \pm 18$ & $17 \pm 23$ & $24 \pm 15$ \\
\hline $\mathrm{GOM}\left[\mathrm{pg} \mathrm{\textrm {m } ^ { - 3 }}\right]^{\mathrm{c}}$ & - & - & - & $4 \pm 10$ & $0.4 \pm 1.3$ & $1.2 \pm 1.1$ & $0.6 \pm 0.6$ & $0.6 \pm 0.5$ \\
\hline GOM DD [ng m $\left.{ }^{-2} \mathrm{~h}^{-1}\right]$ & $0.24 \pm 0.20$ & $0.17 \pm 0.12$ & $0.15 \pm 0.06$ & $0.40 \pm 0.23$ & $0.20 \pm 0.13$ & $0.13 \pm 0.18$ & $0.20 \pm 0.50$ & $0.14 \pm 0.04$ \\
\hline $\mathrm{WS}\left[\mathrm{m} \mathrm{s}^{-1}\right]$ & $2.1 \pm 1.2$ & $2.1 \pm 1.0$ & $2.8 \pm 1.7$ & $2.9 \pm 1.8$ & $2.0 \pm 1.1$ & $2.1 \pm 1.1$ & $2.5 \pm 1.3$ & $2.5 \pm 1.5$ \\
\hline TEMP $\left[{ }^{\circ} \mathrm{C}\right]$ & $26 \pm 3$ & $19 \pm 6$ & $14 \pm 6$ & $18 \pm 6$ & $26 \pm 3$ & $20 \pm 7$ & $11 \pm 7$ & $14 \pm 5$ \\
\hline $\mathrm{RH}[\%]$ & $83 \pm 14$ & $76 \pm 18$ & $79 \pm 19$ & $73 \pm 21$ & $84 \pm 13$ & $77 \pm 17$ & $76 \pm 23$ & $78 \pm 21$ \\
\hline $\mathrm{SR}\left[\mathrm{W} \mathrm{m^{-2 } ]}\right.$ & $230 \pm 302$ & $193 \pm 271$ & $121 \pm 199$ & $266 \pm 304$ & $210 \pm 278$ & $175 \pm 255$ & $129 \pm 212$ & $182 \pm 278$ \\
\hline Precipitation [mm] & 637 & 186 & 385 & 223 & 1010 & 254 & 357 & 183 \\
\hline
\end{tabular}

${ }^{\mathrm{a}}$ Tekran ${ }^{\circledR}$ data. ${ }^{\mathrm{b}}$ Cation-exchange membrane data. ${ }^{\mathrm{c}}$ Nylon membrane data.

jectories for the entire sampling time were analyzed using cluster analysis (Liu et al., 2010).

Sigmaplot 14.0 (Systat Software Inc, San Jose, CA, USA), and Minitab 16.0 (Minitab Inc., PA, US) were used to do $t$ tests and correlation analyses. Comparisons were considered significantly different and correlations were considered significant when $p<0.05$.

\section{Results and discussion}

\subsection{Overall measurements}

Similar to previous work at this location (Gustin et al., 2012), $\mathrm{O}_{3}$ was highest in the spring. $\mathrm{CO}$ concentrations were high in winter, due to a low boundary layer and biomass burning, and low in summer (Table 1). Observations from the three GOM sampling methods (Tekran ${ }^{\circledR}$, and nylon and cation exchange membranes) showed higher GOM concentrations in spring relative to other seasons (Table 1). Concentrations of GOM measured by cation-exchange membranes in the active system were significantly ( $p$ value $<0.05$, paired- $t$ test) higher than those measured by Tekran ${ }^{\circledR} \mathrm{KCl}$-coated denuder and nylon membranes, both of which have been reported to be influenced by relative humidity (Huang and Gustin, 2015b; Gustin et al., 2015). Mean cation-exchange membrane concentrations were higher than Tekran ${ }^{\circledR}$-derived GOM by 14 , 48,11 , and 13 times in the spring, summer, fall, and winter, respectively.

Nylon membranes collected higher GOM concentrations than those measured by the Tekran ${ }^{\circledR}$ in spring 2013 when the humidity was low. Overall, air concentrations measured by the Tekran ${ }^{\circledR}$ system in this study were similar to those measured at OLF in 2010 (Peterson et al., 2012). Particulatebound $\mathrm{Hg}$ had the same seasonal trend as GOM, but higher concentrations.

Understanding the oxidants present in air is important for understanding potential GOM compounds. Oxidants to consider include $\mathrm{O}_{3}$, halogenated compounds, and sulfur and nitrogen compounds (cf. Gustin et al., 2016). Since the active system is currently limited to a 2-week sampling period, they are useful for understanding the specific compounds that might be present, and this in turn can be used to understand sources.

\subsection{Potential GOM compounds}

Standard desorption profiles for GOM compounds obtained by Huang et al. (2013) and Gustin et al. (2015) are compared to those obtained at OLF (Fig. 2). Compounds used as standards included $\mathrm{HgBr}_{2}, \mathrm{HgCl}_{2}, \mathrm{HgN}_{2} \mathrm{O}_{6} \cdot \mathrm{H}_{2} \mathrm{O}, \mathrm{HgSO}_{4}$, and $\mathrm{HgO} . \mathrm{HgCl}_{2}$ and $\mathrm{HgBr}_{2}$ have been identified as being released from permeation tubes (Lyman et al., 2016); however, the exact $\mathrm{N}$ and $\mathrm{S}$ compounds are not known. During 10 periods the nylon membranes (collected in triplicate) collected a significant amount of GOM based on their bi-weekly detection limit (Fig. 2), and the desorption profiles varied. Although data are limited, we have observed similar thermal desorption compounds in other studies (i.e., Huang et al., 2013; Gustin et al., 2016). For example, in the marine boundary layer in Santa Cruz, California, based on the additional curves in Gustin et al. (2015), Hg-nitrogen and sulfur compounds were observed. At the Reno Atmospheric Mercury 


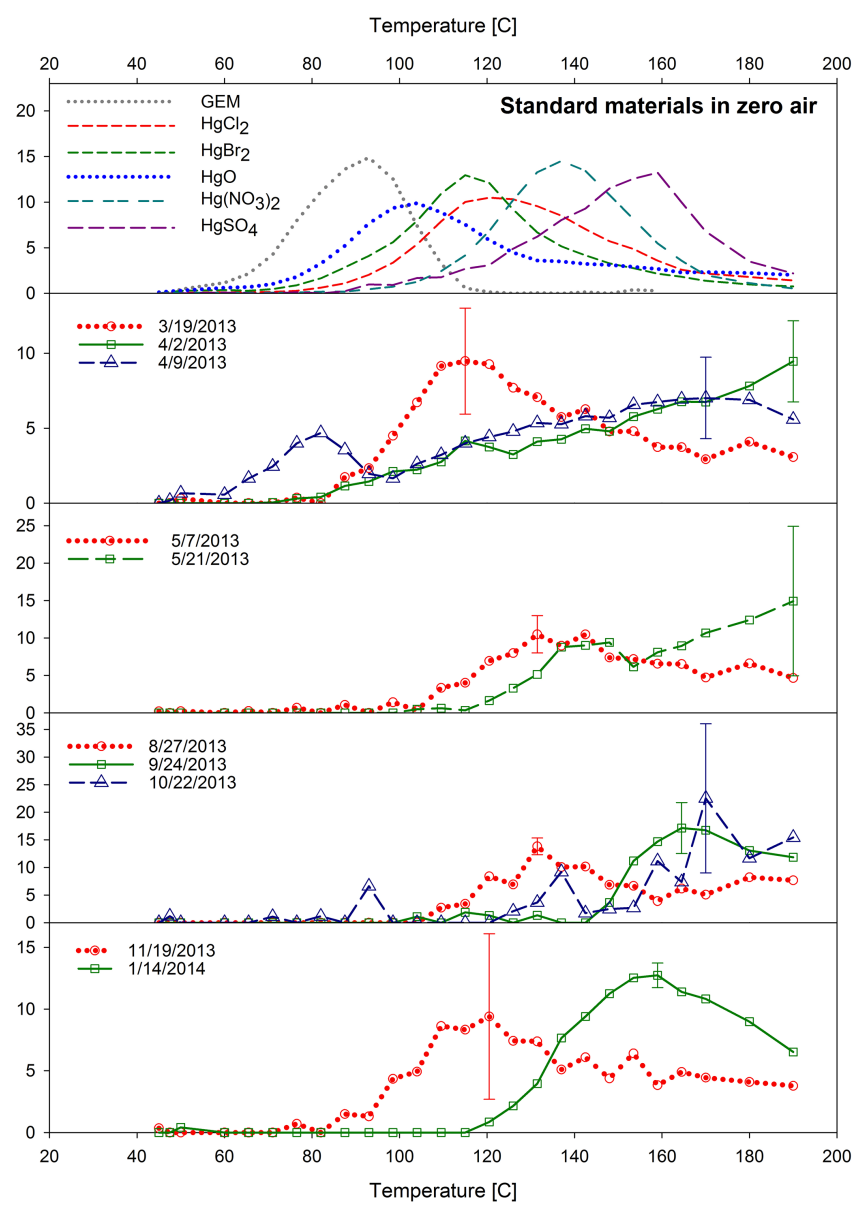

Figure 2. Desorption profiles from nylon membranes with standard materials in laboratory investigation (top) and field measurements. Each whisker is 1 standard variation, and only present in the desorption peak. Note the $\mathrm{Hg}$-nitrogen compound in the permeation tube was $\mathrm{HgN}_{2} \mathrm{O}_{6} \cdot \mathrm{H}_{2} \mathrm{O}$. The $y$ axis indicates the percentage released at each temperature.

Intercomparison Experiment (RAMIX) site, Nevada, Huang et al. (2013) reported $\mathrm{HgBr}_{2} / \mathrm{HgCl}_{2}$ compounds; this is due to free troposphere inputs at this site (Gustin et al., 2013). At a highway-impacted site Huang et al. (2013) reported similar patterns to that in Gustin et al. (2016) that included $\mathrm{Hg}-$ nitrogen and sulfur compounds, and unknown compounds that generated a high residual tail in the profile. This indicates that similar chemical forms are being collected, and is supported by work described below, and that the compounds are not being generated on the membranes. Lack of generation on membranes has also been shown to be the case in a limited study (Pierce and Gustin, 2017). In addition to our work, $\mathrm{HgBr}_{2}$ and $\mathrm{HgCl}_{2}$ were reported to occur in Montreal, Canada (Deeds et al., 2015).

Seven distinct patterns of release were observed from membranes collected at OLF during thermal desorption. One had a high residual tail that does not match our stan- dard profiles; however, this was also observed in Nevada (Gustin et al., 2016). These occurred on 2 and 9 April and 21 May 2013. This suggests that in spring there is a compound that is unknown based on current standard profiles. Based on our methylmercury profile, generated using methylmercury added as a liquid to membranes and presented in Gustin et al. (2015), it is possible this could be some organic compound. A nitrogen-based compound was found on 21 May 2013 based on the desorption profile. A pattern occurred on 19 March and 19 November 2013, and this corresponded to $\mathrm{HgBr}_{2} / \mathrm{HgCl}_{2}$ with some residual tail that is again some compound not accounted for.

Patterns observed on 7 May and 27 August 2013 corresponded to a $\mathrm{Hg}$-nitrogen-based compound with a residual tail. The fifth pattern occurred on 14 January 2014, and 24 September 2013 was associated with $\mathrm{HgSO}_{4}$ and the error bars are small. Data collected on 22 October 2013 was noisy and had subtle peaks that correspond with $\mathrm{HgO}$, a nitrogenbased compound, and a high residual tail. It is interesting to note that the 19 November 2013 profile was similar to $\mathrm{HgCl}_{2}$.

Previous studies reported consistent desorption profiles from three sites in Nevada and California without significant point sources (Huang et al., 2013). Huang et al. (2013) presented desorption profiles from a highway, agriculture, and marine boundary layer site. Profiles from the marine boundary layer and agriculture-impacted site did not show clear residual tails at $185^{\circ} \mathrm{C}$, but these were observed at the highway-impacted site. At OLF, a significant amount of GOM (15-30\%) was released after $160^{\circ} \mathrm{C}$. This and previous work implies that we are missing one or more GOM compound(s) (Fig. 2) in our permeation profiles. Interestingly, a peak was found in the 9 April 2013 sample at the GEM release temperature; this is not due to GEM absorption as demonstrated by Huang et al. (2013), and was also observed in Nevada (Gustin et al., 2016), suggesting an additional unidentified compound. This information indicates GOM compounds at OLF varied with time, and this variation is due to complicated $\mathrm{Hg}$ emission sources and chemistry at this location (cf. Gustin et al., 2012).

At OLF, GOM composition on the nylon membrane was more complicated than that collected at rural sites in the western USA (cf. Huang et al., 2013; Gustin et al., 2016); however, similar complexity was observed at a highway location in Reno, Nevada (Gustin et al., 2016). Desorption curves from the nylon filters collected at rural locations in Nevada were in the range of the standard GOM compounds that have been investigated (Huang et al., 2013; Gustin et al., 2016). Curves with multiple peaks in this study imply that there were at least seven GOM compounds collected on the nylon membranes.

\subsection{Dry-deposition measurements}

Dry deposition of GOM measured by Aerohead samplers ranged from 0 to $0.5 \mathrm{ng} \mathrm{m}^{-2} \mathrm{~h}^{-1}$, and $83 \%$ of 


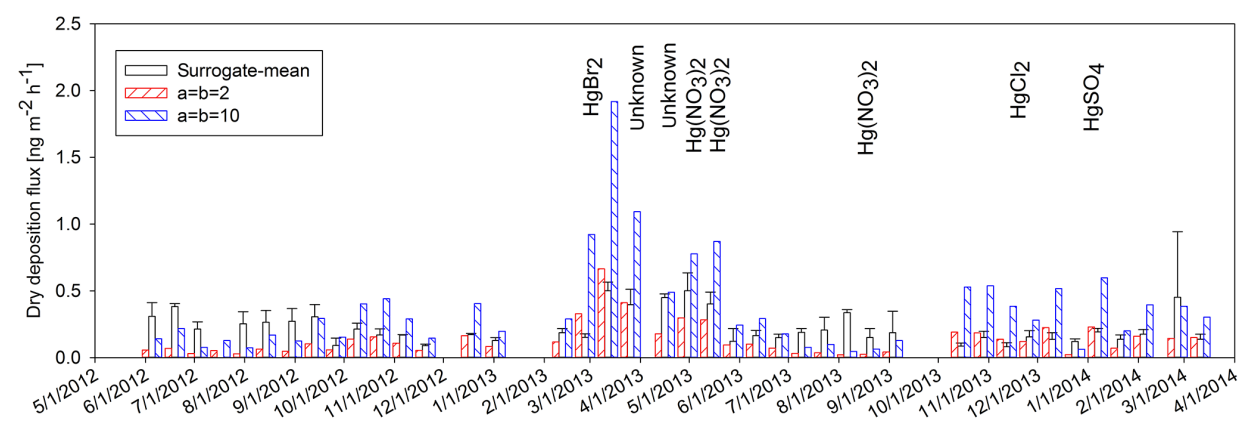

Figure 3. Measured and modeled GOM dry-deposition fluxes. Tekran ${ }^{\circledR}$ data (correction factor of 3) were used with multiple resistance models ( $\alpha=\beta=2$ and 10). Tentative GOM compounds were determined using the results from nylon membrane desorption.

GOM dry deposition was higher than the detection limit $\left(0.13 \mathrm{ng} \mathrm{m}^{-2} \mathrm{~h}^{-1}\right)$. Higher GOM dry deposition was observed in spring relative to winter (ANOVA one-way rank, $p$ value $<0.01$ ); GOM dry deposition was slightly lower in summer and fall (not statistically different) relative to the spring due to high wet deposition and scavenging processes during these seasons. The pattern in GOM seasonal dry deposition was similar to that reported by Peterson et al. (2012). However, GOM dry-deposition rates were significantly higher in this study than 2010 values $\left(0.2\right.$ vs. $\left.0.05 \mathrm{ng} \mathrm{m}^{-2} \mathrm{~h}^{-1}\right)$. This is due to the correction of $0.2 \mathrm{ng} \mathrm{m}^{-2} \mathrm{~h}^{-1}$ applied in Peterson et al. (2012) to account for contamination of the Aerohead that has been demonstrated to be unnecessary (Huang et al., 2014). Although the highest GOM dry deposition measured using the Aerohead sampler and GOM concentrations measured using the UNRRAMS were observed in spring 2013, the value in March 2014 was relatively low. In March 2014, atmospheric conditions were more similar to winter than spring, with low temperatures and high $\mathrm{CO}$ concentrations. These results are different from those calculated using Tekran ${ }^{\circledR}$ measurements that suggest low GOM concentrations and high deposition velocities, and this is because the denuder measurements are biased low.

Modeled GOM dry-deposition fluxes were calculated using GOM concentrations measured by the Tekran ${ }^{\circledR}$ system that were multiplied by a factor of 3 (cf. Huang et al., 2014). In general, measured $\mathrm{Hg}$ dry-deposition fluxes were similar to those modeled simulations with GOM dry deposition $\alpha=\beta=2$ during winter, spring, and fall (see below; Fig. 3). Measured $\mathrm{Hg}$ dry deposition was significantly higher than modeled results (both $\alpha=\beta=2$ and 10) in summer and early fall (Fig. 3). This indicates that there are compounds of GOM in the summer that are poorly collected by the denuder, and this also can help explain the higher wet deposition measured during this season (Prestbo and Gay, 2009). Highest deposition was measured during the spring, when the input from long-range transport is greatest (Gustin et al., 2012). Figure 3 shows the disparity that occurs by season, and compares model and measured values. For example in spring $a=b=10$ significantly overestimates deposition, while in the summer and early fall measured deposition is greater than modeled values.

Because of the low GOM concentrations and influence of humidity on the nylon membrane measurements (Huang and Gustin, 2015b), GOM compounds were identified only in one summertime sample as $\mathrm{HgN}_{2} \mathrm{O}_{6} \cdot \mathrm{H}_{2} \mathrm{O}$. During this time, measured GOM dry deposition was $\sim 6$ times higher than both modeled results, and considering the $\mathrm{Tekran}^{\circledR}$ correction factor of 3, membranebased $\mathrm{HgN}_{2} \mathrm{O}_{6} \cdot \mathrm{H}_{2} \mathrm{O}$ dry-deposition flux was $\sim 18$ times higher than the Tekran ${ }^{\circledR}$-model-based value. Gustin et al. (2015) indicated $\mathrm{HgN}_{2} \mathrm{O}_{6} \cdot \mathrm{H}_{2} \mathrm{O}$ collection efficiency on cation-exchange membrane in charcoal scrubbed air was $\sim 12.6$ times higher than on the Tekran ${ }^{\circledR} \mathrm{KCl}$-coated denuder.

However, in May 2013, two samples were dominated by a profile similar to the $\mathrm{Hg}$ nitrogen-based compound with lower measured-to-modeled ratios (2.1-6.0 with Tekran ${ }^{\circledR}$ correction factor). This might be due to ambient air GOM chemistry being dominated by a compound with a different dry-deposition velocity, less interference on the denuder surface, or parameters in the dry-deposition scheme. In May, GOM concentrations measured by the Tekran ${ }^{\circledR}$ were higher than in summer due to lower wet deposition and mean humidity (Table 1). Therefore, despite the fact that GOM collection efficiency associated with the Tekran ${ }^{\circledR}$ and nylon membranes are impacted by environmental conditions, this demonstrates the presence of different compounds in the air. The dry-deposition scheme needs Henry's Law constants for determining the scaling factors for specific resistances for different compounds (Lyman et al., 2007; Zhang et al., 2002).

Lin et al. (2006) stated that the dry-deposition velocity of $\mathrm{HgO}$ is 2-times higher than that for $\mathrm{HgCl}_{2}$, due to the different Henry's Law constant. The Henry's Law constants for $\mathrm{HgCl}_{2}, \mathrm{HgBr}_{2}$, and $\mathrm{HgO}$ presented in previous literature (Schroeder and Munthe, 1998) have high uncertainty, for how these calculations were done is not clear (S. Lyman, Utah State University, personal communication, 2015), and the constants for $\mathrm{HgN}_{2} \mathrm{O}_{6} \cdot \mathrm{H}_{2} \mathrm{O}$ and $\mathrm{HgSO}_{4}$ are un- 


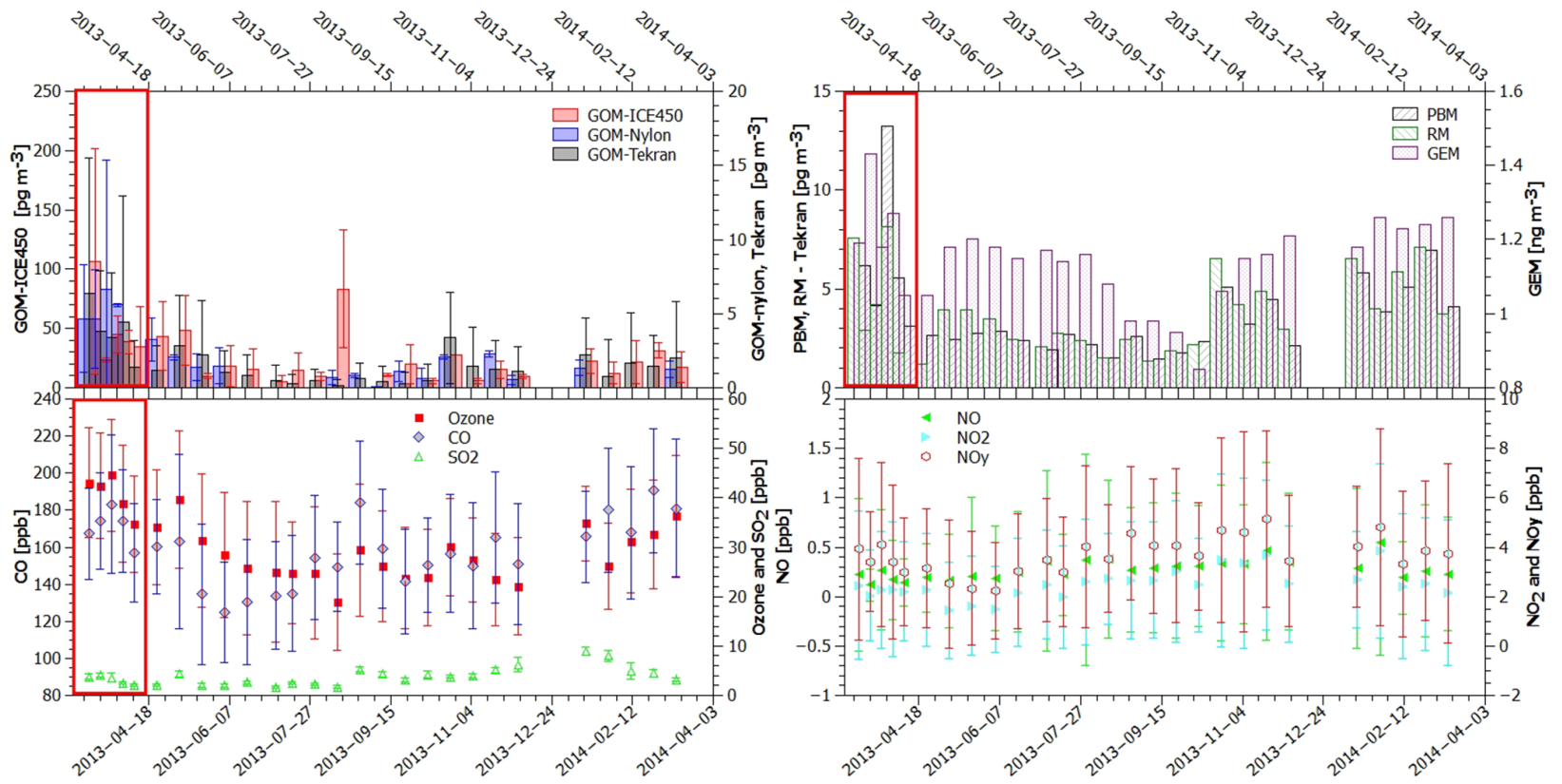

Figure 4. Temporal variation of GOM concentrations (mean \pm standard deviation, bi-week average); outlined rectangle indicates a polluted event with high $\mathrm{Hg}, \mathrm{CO}$, and ozone concentrations. Data are missing for 3 weeks because it was not collected. Tekran ${ }^{\circledR}$ data are presented when $>75 \%$ of the data were available and membrane data are shown when above the method detection limit.

Table 2. Modeled (multiple-resistance model) and measured (surrogate surfaces) GOM dry deposition (ng m ${ }^{-2} \mathrm{~h}^{-1}$ ); GOM concentrations used to calculate for modeled results are from the Tekran ${ }^{\circledR}$ data and corrected by compounds' corresponding ratios from Gustin et al. (2015, 2016). Model resistance for the unknown compound was calculated using the Tekran ${ }^{\circledR}$ data multiplied by 3 . The tentative GOM compounds are identified from nylon membrane results.

\begin{tabular}{|c|c|c|c|c|c|c|}
\hline Start date & $\begin{array}{l}\text { Tentative GOM } \\
\text { compound }\end{array}$ & $\begin{array}{r}\text { Measured GOM } \\
\text { dry deposition } \\
\text { flux }\end{array}$ & $\begin{array}{r}\text { Modeled GOM } \\
\text { dry deposition } \\
\alpha=\beta=2\end{array}$ & $\begin{array}{r}\text { Modeled GOM } \\
\text { dry deposition } \\
\alpha=\beta=5\end{array}$ & $\begin{array}{r}\text { Modeled GOM } \\
\text { dry deposition } \\
\alpha=\beta=7\end{array}$ & $\begin{array}{r}\text { Modeled GOM } \\
\text { dry deposition } \\
\alpha=\beta=10\end{array}$ \\
\hline $12 \operatorname{Mar} 2013$ & $\mathrm{HgBr}_{2}$ & $0.50 \pm 0.06$ & 0.34 & 0.49 & 0.54 & 0.58 \\
\hline $26 \operatorname{Mar} 2013$ & unknown & $0.40 \pm 0.11$ & 0.34 & 0.47 & 0.52 & 0.56 \\
\hline 30 Apr 2013 & $\mathrm{Hg}\left(\mathrm{NO}_{3}\right)_{2}$ & $0.50 \pm 0.13$ & 1.21 & 1.67 & 1.81 & 1.95 \\
\hline 14 May 2013 & $\mathrm{Hg}\left(\mathrm{NO}_{3}\right)_{2}$ & $0.40 \pm 0.09$ & 1.19 & 1.69 & 1.88 & 2.07 \\
\hline 20 Aug 2013 & $\mathrm{Hg}\left(\mathrm{NO}_{3}\right)_{2}$ & $0.15 \pm 0.07$ & 0.10 & 0.14 & 0.16 & 0.17 \\
\hline 12 Nov 2013 & $\mathrm{HgCl}_{2}$ & $0.08 \pm 0.03$ & 0.11 & 0.16 & 0.17 & 0.19 \\
\hline 7 Jan 2014 & $\mathrm{HgSO}_{4}$ & $0.19 \pm 0.03$ & 0.18 & 0.24 & 0.27 & 0.29 \\
\hline
\end{tabular}

known. Some researchers considered that GOM is similar to $\mathrm{HNO}_{3}(\alpha=\beta=10)$, and some treated GOM as HONO $(\alpha=\beta=2$ ) (Castro et al., 2012; Lyman et al., 2007; Marsik et al., 2007); however, using the parameters of $\mathrm{HNO}_{3}$ could overestimate GOM dry-deposition velocities due to the differences of effective Henry's law constants $\left(\mathrm{HgCl}_{2}\right.$ : $\left.\sim 10^{6} \mathrm{HNO}_{3}: \sim 10^{13} \mathrm{Matm}^{-1}\right)$.

If the ratios $\left(\mathrm{HgBr}_{2}: 1.6, \mathrm{HgCl}_{2}: 2.4, \mathrm{HgSO}_{4}: 2.3\right.$, $\mathrm{HgO}: 3.7$, and $\left.\mathrm{HgN}_{2} \mathrm{O}_{6} \cdot \mathrm{H}_{2} \mathrm{O}: 12.6\right)$ of GOM concentrations measured by the Tekran ${ }^{\circledR}$ vs. cation-exchange membranes for different GOM-permeated compounds (Gustin et al., 2015; Huang et al., 2013) are used to correct Tekran ${ }^{\circledR}$ GOM data in this study, modeled GOM dry deposition
(Fig. 3) is not correlated with measurements. For example, on 9 March and 19 November 2013 (Fig. 3), GOM was dominated by $\mathrm{HgBr}_{2}$ and $\mathrm{HgCl}_{2}$. Dry deposition of $\mathrm{HgBr}_{2}$ from Aerohead measurements and modeling were close to $\alpha=\beta=10$; however, modeled and measured $\mathrm{HgCl}_{2}$ dry deposition were matched as $\alpha=\beta=2$. Average deposition velocity for $\alpha=\beta=2$ was $0.78 \mathrm{~cm} \mathrm{~s}^{-1}$, and for $\alpha=\beta=$ 10 is $1.59 \mathrm{~cm} \mathrm{~s}^{-1}$, if we assume the model is right. There were three samples that were identified as $\mathrm{Hg}$-nitrogenbased compounds using nylon membranes; however, the ratios of measurement and modeling $\mathrm{HgN}_{2} \mathrm{O}_{6} \cdot \mathrm{H}_{2} \mathrm{O}$ dry deposition were inconsistent over time. In spring, all modeled $\mathrm{HgN}_{2} \mathrm{O}_{6} \cdot \mathrm{H}_{2} \mathrm{O}$ dry-deposition values were much higher than 
measured values; however, in summer, measured and modeled $\mathrm{HgN}_{2} \mathrm{O}_{6} \cdot \mathrm{H}_{2} \mathrm{O}$ dry deposition were similar as $\alpha=\beta=$ 5 (Table 2). If you assume the dry-deposition measurements made by the surrogate surfaces are accurate then this demonstrates that there are different forms that occur over time, and these will have different deposition velocities, as suggested by Peterson et al. (2012).

\subsection{Elevated pollution event}

In spring 2013, there was a time period when concentrations of $\mathrm{O}_{3}, \mathrm{CO}$, and all $\mathrm{Hg}$ measured were high (Fig. 4). Figure 5 shows that during this time, air masses traveled west to east across the continent. The air movement pattern is similar to that found in Gustin et al. (2012) for OLF Class 2 events which had low $\mathrm{SO}_{2}$ concentrations. During this 4-week period, air parcels traveling to OLF were in the free troposphere and descended to the surface (Fig. 5). Although there are coal-fired power plants in the upwind area within a $500 \mathrm{~km}$ range (Fig. 1), the low $\mathrm{SO}_{2}$ concentrations and elevated $\mathrm{CO}, \mathrm{O}_{3}$, and $\mathrm{GOM}$ values were not from fossil fuel combustion. Gustin et al. (2012) also indicated that free troposphere air impacted OLF. The first few endpoints for these trajectories indicate that air parcels entered North America at $>1000 \mathrm{~m}$ a.g.l.; therefore, there was transport of some air measured during this time from the free troposphere. Ozone concentrations were also similar to those measured in Nevada in the free troposphere at this time (Gustin et al., 2014). It is important to note that the back trajectories are only for $72 \mathrm{~h}$ and the ones that subsided to surface levels in the midwestern USA were traveling fast. This is a common event in the spring that represents free troposphere and/or stratosphere transport into the western USA and Florida (Gertler and Bennett, 2015; Lefohn and Cooper, 2015; Weiss-Penzias et al., 2011; Gustin et al., 2012).

The chemical composition of this event suggests potential input from Asia, as previously suggested, for three locations in Florida in the spring by Gustin et al. (2012). During this time, based on thermal desorption profiles, $\mathrm{HgBr}_{2}$ was measured initially and then the following profiles obtained showed a gradual increase in GOM with increasing temperature with a high residual tail. This would suggest initial subsidence of air from the stratosphere and/or troposphere (cf. Lyman and Jaffe, 2012) followed by a mixture of polluted air as observed in the western USA (cf. VanCuren and Gustin, 2015).

\section{Conclusions}

The chemical forms of GOM in the atmosphere at OLF varied by season as suggested by Gustin et al. (2012). Seven potential different GOM compounds were identified at OLF using nylon membranes with thermal desorption analysis, including $\mathrm{HgBr}_{2}, \mathrm{HgCl}_{2}, \mathrm{HgO}, \mathrm{Hg}$-nitrogen and sulfur com-

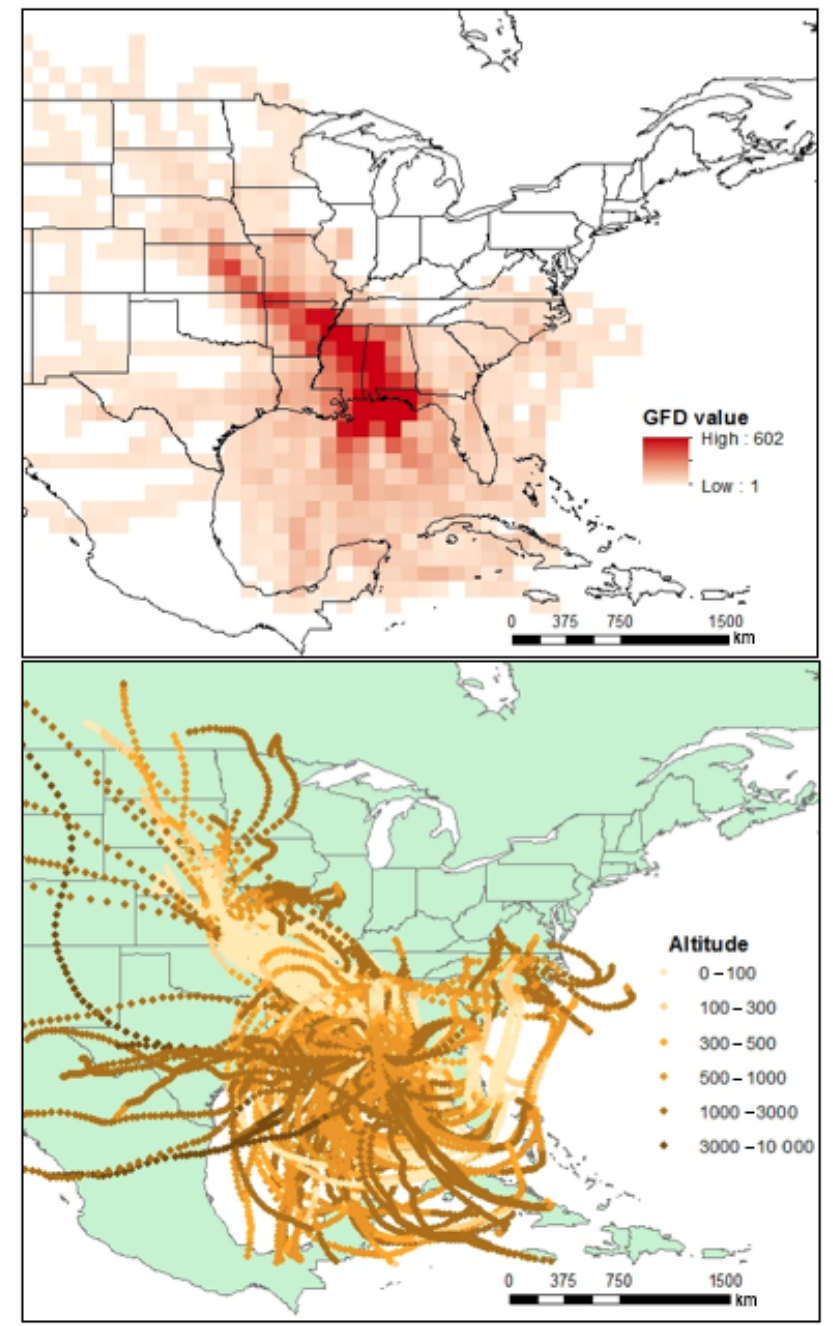

Figure 5. Results of gridded frequency distribution (top panel); light color indicates less endpoints in a grid. Altitude of $72 \mathrm{~h}$ trajectories (bottom panel) during the polluted event (12 March2 April 2013); light color of dots on left panel represents low altitude.

pounds, and two unknown compounds. Given the long sampling time, detailed assessment of specific sources is difficult, but the presence of different compounds indicates multiple sources and different GOM chemistry. Comparing modeled and measured $\mathrm{Hg}$ dry-deposition fluxes also demonstrates that there are different forms in air and this will affect drydeposition velocities. In order to measure GOM accurately, we need to know what compounds exist in the atmosphere.

\section{Data availability}

Data are available upon request from the first author Jiaoyan Huang (huangj1311@gmail.com). 
Competing interests. The authors declare that they have no conflict of interest.

Acknowledgements. The authors thank The Southern Company (project manager - John Jansen) for their support, and Bud Beghtel for deploying and collecting our membranes and passive samplers at OLF, and managing this site in general. This work was also supported by EPRI and the National Science Foundation grant 1326074 . We thank the following students for coordinating shipment of membranes and passive samplers, analyses of the membranes in the lab, and keeping the glassware clean: Keith Heidecorn, Douglas Yan, Matt Peckham, Jennifer Arnold, Jen Schoener, and Addie Luippold.

Edited by: L. Zhang

Reviewed by: two anonymous referees

\section{References}

Ambrose, J. L., Lyman, S. N., Huang, J., Gustin, M. S., and Jaffe, D. A.: Fast Time Resolution Oxidized Mercury Measurements during the Reno Atmospheric Mercury Intercomparison Experiment (RAMIX), Environ. Sci. Technol., 47, 7285-7294, 2013.

Caffrey, J. M., Landing, W. M., Nolek, S. D., Gosnell, K. J., Bagui, S. S., and Bagui, S. C.: Atmospheric deposition of mercury and major ions to the Pensacola (Florida) watershed: spatial, seasonal, and inter-annual variability, Atmos. Chem. Phys., 10, 5425-5434, doi:10.5194/acp-10-5425-2010, 2010.

Castro, M. S., Moore, C., Sherwell, J., and Brooks, S. B.: Dry deposition of gaseous oxidized mercury in Western Maryland, Sci. Total Environ., 417-418, 232-240, 2012.

Deeds, D. A., Ghoshdastidar, A., Raofie, F., Guerette, E. A., Tessier, A., and Ariya, P. A.: Development of a Particle-Trap Preconcentration-Soft Ionization Mass Spectrometric Technique for the Quantification of Mercury Halides in Air, Anal. Chem., 87, 5109-5116, 2015.

Draxler, R.: What are the levels of uncertainty associated with back trajectory calculations in HYSPLIT, NOAA, 2013.

Dvonch, J. T., Graney, J. R., Keeler, G. J., and Stevens, R. K.: Use of Elemental Tracers to Source Apportion Mercury in South Florida Precipitation, Environ. Sci. Technol., 33, 4522-4527, 1999.

Gebhart, K. A., Schichtel, B. A., and Barma, M. G.: Directional biases in back trajectories caused by model and input data, J. Air Waste Manage., 55, 1649-1662, 2005.

Gertler, A. and Bennett, J.: The Nevada Rural Ozone Initiative: A framework for developing an understanding of factors contributing to elevated ozone concentrations in rural and remote environments, Sci. Total Environ., 530, 453-454, 2015.

Gustin, M. S., Weiss-Penzias, P. S., and Peterson, C.: Investigating sources of gaseous oxidized mercury in dry deposition at three sites across Florida, USA, Atmos. Chem. Phys., 12, 9201-9219, doi:10.5194/acp-12-9201-2012, 2012.

Gustin, M. S., Huang, J., Miller, M. B., Peterson, C., Jaffe, D. A., Ambrose, J., Finley, B. D., Lyman, S. N., Call, K., Talbot, R., Feddersen, D., Mao, H., and Lindberg, S. E.: Do We Understand
What the Mercury Speciation Instruments Are Actually Measuring? Results of RAMIX, Environ. Sci. Technol., 47, 7295-7306, 2013.

Gustin, M. S., Amos, H. M., Huang, J., Miller, M. B., and Heidecorn, K.: Measuring and modeling mercury in the atmosphere: a critical review, Atmos. Chem. Phys., 15, 5697-5713, doi:10.5194/acp-15-5697-2015, 2015.

Gustin, M. S., Pierce, A. M., Huang, J., Miller, M. B., Holmes, H. S., and Loria-Salazar, S. M.: Evidence for different reactive $\mathrm{Hg}$ sources and chemical compounds at adjacent valley and high elevation locations, Environ. Sci. Technol., 50, 12225-12231, 2016.

Huang, J. and Gustin, M.: Uncertainties of Gaseous Oxidized Mercury Measurements Using KCl-coated Denuders, CationExchange Membranes, and Nylon Membranes: Humidity Influences, Environ. Sci. Technol., 49, 432-441, 2015a.

Huang, J. and Gustin, M. S.: Use of passive sampling methods and models to understand sources of mercury deposition to high elevation sites in the Western United States, Environ. Sci. Technol., 49, 432-441, doi:10.1021/es502836w, 2015b.

Huang, J., Miller, M. B., Weiss-Penzias, P., and Gustin, M. S.: Comparison of Gaseous Oxidized $\mathrm{Hg}$ Measured by KCl-Coated Denuders, and Nylon and Cation Exchange Membranes, Environ. Sci. Technol., 47, 7307-7316, 2013.

Huang, J., Lyman, S. N., Hartman, J. S., and Gustin, M. S.: A review of passive sampling systems for ambient air mercury measurements, Environmental Science: Processes \& Impacts, 16, 374 392, 2014.

Lefohn, A. S. and Cooper, O. R.: Introduction to the special issue on observations and source attribution of ozone in rural regions of the western United States Preface, Atmos. Environ., 109, 279281, 2015.

Lin, C.-J., Pongprueksa, P., Lindberg, S. E., Pehkonen, S. O., Byun, D., and Jang, C.: Scientific uncertainties in atmospheric mercury models I: Model science evaluation, Atmos. Environ., 40, 29112928, 2006.

Lindberg, S. E., Bullock, R., Ebinghaus, R., Engstrom, D., Feng, X., FItzgerald, W., Pirrone, N., Prestbo, E., and Seigneur, C.: A synthesis of progress and uncertainites in attributing the sources of mercury in deposition, AMBIO, 36, 19-32, 2007.

Liu, B., Keeler, G. J., Timothy Dvonch, J., Barres, J. A., Lynam, M. M., Marsik, F. J., and Morgan, J. T.: Urban-rural differences in atmospheric mercury speciation, Atmos. Environ., 44, 20132023, 2010.

Lyman, S., Jones, C., O’Neil, T., Allen, T., Miller, M., Gustin, M., Pierce, A., Luke, W., Ren, X., and Kelley, P.: Automated Calibration of Atmospheric Oxidized Mercury Measurements, Environ. Sci. Technol., 50, 12921-12927, 2016.

Lyman, S. N. and Jaffe, D. A.: Formation and fate of oxidized mercury in the upper troposphere and lower stratosphere, Nat. Geosci., 5, 114-117, 2012.

Lyman, S. N., Gustin, M. S., Prestbo, E. M., and Marsik, F. J.: Estimation of Dry Deposition of Atmospheric Mercury in Nevada by Direct and Indirect Methods, Environ. Sci. Technol., 41, 19701976, 2007.

Lyman, S. N., Gustin, M. S., Prestbo, E. M., Kilner, P. I., Edgerton, E., and Hartsell, B.: Testing and Application of Surrogate Surfaces for Understanding Potential Gaseous Oxidized Mercury Dry Deposition. Environ. Sci. Technol., 43, 6235-6241, 2009. 
Lyman, S. N., Jaffe, D. A., and Gustin, M. S.: Release of mercury halides from $\mathrm{KCl}$ denuders in the presence of ozone, Atmos. Chem. Phys., 10, 8197-8204, doi:10.5194/acp-10-81972010, 2010.

Marsik, F. J., Keeler, G. J., and Landis, M. S.: The dry-deposition of speciated mercury to the Florida Everglades: Measurements and modeling, Atmos. Environ., 41, 136-149, 2007.

McClure, C. D., Jaffe, D. A., and Edgerton, E. S.: Evaluation of the $\mathrm{KCl}$ Denuder Method for Gaseous Oxidized Mercury using $\mathrm{HgBr}_{2}$ at an In-Service AMNet Site, Environ. Sci. Technol., 48, 11437-11444, 2014.

MDN: available at: http://nadp.sws.uiuc.edu/MDN/ annualmdnmaps.aspx (last access: 13 November 2016), 2014.

Nair, U. S., Wu, Y., Holmes, C. D., Ter Schure, A., Kallos, G., and Walters, J. T.: Cloud-resolving simulations of mercury scavenging and deposition in thunderstorms, Atmos. Chem. Phys., 13, 10143-10157, doi:10.5194/acp-13-10143-2013, 2013.

NOAA: Eta Data Assimilation System (EDAS40) Archive Information, Silver Spring, MD, 2008.

Pancras, J. P., Vedantham, R., Landis, M. S., Norris, G. A., and Ondov, J. M.: Application of EPA Unmix and Nonparametric Wind Regression on High Time Resolution Trace Elements and Speciated Mercury in Tampa, Florida Aerosol, Environ. Sci. Technol., 45, 3511-3518, 2011.

Peterson, C., Alishahi, M., and Gustin, M. S.: Testing the use of passive sampling systems for understanding air mercury concentrations and dry deposition across Florida, USA, Sci. Total Environ., 424, 297-307, 2012.

Pierce, A. M. and Gustin, M. S.: Development of a particulate mass measurement system for tracing pollution sources using atmospheric mercury concentrations, Environ. Sci. Technol., 51, 436445, 2017.
Prestbo, E. M. and Gay, D. A.: Wet deposition of mercury in the U.S. and Canada, 1996-2005: Results and analysis of the NADP mercury deposition network (MDN), Atmos. Environ., 43, 42234233, 2009.

Schroeder, W. H. and Munthe, J.: Atmospheric mercury - An overview, Atmos. Environ., 32, 809-822, 1998.

Stohl, A.: Computation, accuracy and applications of trajectories a review and bibliography, Atmos. Environ., 32, 947-966, 1998.

Stohl, A., Forster, C., Eckhardt, S., Spichtinger, N., Huntrieser, H., Heland, J., Schlager, H., Wilhelm, S., Arnold, F., and Cooper, O.: A backward modeling study of intercontinental pollution transport using aircraft measurements, J. Geophys. Res., 108, 4370, doi:10.1029/2002JD002862, 2003.

UNEP: Global Merucry Assessment 2013 - Sources, Emissions, Releases, and Environmental Transport, UNEP Division of Technology, Industry and Economics, Chemicals Branch International Environment House, Geneva, Switzerland, 2013.

VanCuren, R. and Gustin, M. S.: Identification of sources contributing to $\mathrm{PM}_{2.5}$ and ozone at elevated sites in the western US by receptor analysis: Lassen Volcanic National Park, California, and Great Basin National Park, Nevada, Sci. Total Environ., 530, 505-518, 2015.

Weiss-Penzias, P. S., Gustin, M. S., and Lyman, S. N.: Sources of gaseous oxidized mercury and mercury dry deposition at two southeastern U.S. sites, Atmos. Environ., 45, 4569-4579, 2011.

Zhang, L., Moran, M. D., Makar, P. A., Brook, J. R., and Gong, S.: Modelling gaseous dry deposition in AURAMS: a unified regional air-quality modelling system, Atmos. Environ., 36, 537560, 2002. 